\title{
Extended family structure in the ant Formica paralugubris: the role of the breeding system
}

\begin{abstract}
In populations of various ant species, many queens reproduce in the same nest (polygyny), and colony boundaries appear to be absent with individuals able to move freely between nests (unicoloniality). Such societies depart strongly from a simple family structure and pose a potential challenge to kin selection theory, because high queen number coupled with unrestricted gene flow among nests should result in levels of relatedness among nestmates close to zero. This study investigated the breeding system and genetic structure of a highly polygynous and largely unicolonial population of the wood ant Formica paralugubris. A microsatellite analysis revealed that nestmate workers, reproductive queens and reproductive males (the queens' mates) are all equally related to each other, with relatedness estimates centring around 0.14 . This suggests that most of the queens and males reproducing in the study population had mated within or close to their natal nest, and that the queens did not disperse far after mating. We developed a theoretical model to investigate how the breeding system affects the relatedness structure of polygynous colonies. By combining the model and our empirical data, it was estimated that about $99.8 \%$ of the reproducing queens and males originated from within the nest, or from a nearby nest. This high rate of local mating and the rarity of long-distance dispersal maintain significant relatedness among nestmates, and contrast with the common view that unicoloniality is coupled with unrestricted gene flow among nests.
\end{abstract}

M. Chapuisat $(\bowtie) \cdot$ L. Keller

Institute of Ecology, University of Lausanne

CH-1015 Lausanne, Switzerland

Fax: + 41-21-6924105

M. Chapuisat

Museum of Zoology

CP 448, CH-1000 Lausanne 17, Switzerland

M. Chapuisat

Department of Genetics, La Trobe University

Bundoora, Victoria 3083, Australia
Key words Dispersal - Kin selection - Queen number · Formica paralugubris $\cdot$ Ants $\cdot$ Microsatellites

\section{Introduction}

The evolution and maintenance of reproductive altruism in insect societies can be explained by kin selection when workers favour the reproduction of related individuals, and by so doing indirectly transmit copies of their own genes to the next generation (Hamilton 1963, 1964a, 1964b). In colonies where a single queen reproduces, individuals are highly related and kin selection is undoubtedly the main selective force responsible for the evolution and maintenance of reproductive altruism. However, social structures and mating systems vary greatly both within and between ant species, with concomitant variation in levels of relatedness (Bourke and Franks 1995; Crozier and Pamilo 1996). In some species, colonies contain a very high number of queens (Hölldobler and Wilson 1977), with the effect that colony members are only distantly related (reviewed in Hölldobler and Wilson 1990; Keller 1995; Crozier and Pamilo 1996). Moreover, in such highly polygynous populations, colony boundaries seem frequently absent, with individuals being able to move freely between nests (unicolonial populations: Wilson 1971).

The evolutionary causes and consequences of high queen number and unicoloniality are strongly dependent on the effective amount of gene flow among nests. The conventional wisdom is that gene flow among all nests of a unicolonial population is high. Gene flow among distant nests induces a genetic homogenisation of the population, which, in association with high queen number, results in levels of nestmate relatedness being indistinguishable from zero (Bourke and Franks 1995; Crozier and Pamilo 1996). Thus, kin selection cannot account for the persistence of reproductive altruism in such populations. Ultimately, the success of such unicolonial populations with unrestricted gene 
flow is best explained by short-term ecological benefits in new, disturbed or empty habitat (Bourke and Franks 1995).

In some unicolonial populations, however, gene flow among distant nests might be restricted, even if no clearcut colony boundaries or overt aggression among nests is detected. Thus, an alternative scenario is that high queen number per nest and cooperative networks of nests are selected for by strong constraints on dispersal and progressive habitat saturation (Herbers 1986; Nonacs 1988; Bourke and Heinze 1994; Keller 1995). A low probability of successful dispersal may promote the acceptance of daughter queens in established colonies provided that these queens are more related to workers than non-nestmate queens from the same population. Progressive habitat saturation may then be accompanied by a continuous increase in queen number, a steady decrease in nestmate relatedness, and the formation of large groups of interconnected nests that arise through budding of existing nests (Keller 1995). A prediction of this model is that nestmates should be related, because most queens and males are recruited locally. Hence, kin selection may still play a role in the maintenance of altruism in such unicolonial populations with restricted gene flow.

A better understanding of the causes and consequences of high queen number and apparent absence of colony boundaries thus requires genetic data on the mating system and dynamics of queen recruitment. These components of the breeding system (sensu Ross 1993) can be assessed with the help of highly polymorphic DNA markers. PCR-based markers such as microsatellites are particularly useful for this purpose, because the genotype of reproductive males can be directly determined from the sperm stored in the queens' spermatheca (Peters et al. 1995; Chapuisat 1998). Hence, the relatedness between breeders can be measured, both within and between sexes. These relatedness values are crucial to our understanding of unicoloniality, for two reasons. First, they reflect the dispersal and mating strategies of males and females. For example, queens and males reproducing in their natal nest will tend to have the same relatedness as workers, as all of them arose as nestmates. Secondly, a positive relatedness among breeders due to intranidal mating and limited dispersal will in turn increase the relatedness among workers, which may favour the maintenance of altruism in insect colonies with high queen number.

The aim of the work reported here was to study the relatedness structure and breeding system of a highly polygynous and largely unicolonial population of the wood ant Formica paralugubris. In the study population, field observations revealed that nests contain about 1000 queens (Cherix 1980, 1983; M. Chapuisat, personal observation), and genetic data confirmed that many queens do actually reproduce in each nest (Pamilo et al. 1992; Chapuisat et al. 1997). About 1200 nests form a large supercolony that is characterized by a high density of interconnected and mutually tolerant nests (Gris and
Cherix 1977; Cherix 1980). In this population, queens and males show alternative dispersal strategies. Sexuals can mate and stay within their natal nest, or participate in a mating flight ensuring long-distance dispersal (Cherix et al. 1991). Dispersing individuals mate on open meadows located outside the supercolony (Cherix et al. 1993). After mating, queens must seek adoption in an existing nest of the same species (Fortelius et al. 1993), or parasitize the nest of Serviformica ants (Kutter 1977), as they do not have enough energetic reserves to found new nests independently (Keller and Passera 1989). Hence, the relative proportion of queens and males that mate and reproduce locally and of queens that are adopted into foreign nests after having mated with unrelated males will have a profound impact on the genetic structure of nests and colonies. Genetic data from workers revealed that long-distance gene flow is limited (Chapuisat et al. 1997). Moreover, nearby nests in the supercolony are more similar genetically than distant nests, which indicates that nests often arose as buds of neighbouring nests (Chapuisat et al. 1997).

The essential features of the breeding system of this $F$. paralugubris population were inferred with microsatellite markers. This study expands our previous survey (Chapuisat et al. 1997) by measuring relatedness among workers from a novel set of nests, and by providing the first estimates of relatedness among reproductive queens and reproductive males. We then elaborated a theoretical model investigating how a breeding system with recurrent intranidal mating and recruitment of new reproductive individuals from within the nest affects the level of relatedness. Finally, the model and genetic data were combined to quantify the proportion of reproductive individuals that are recruited locally in this highly polygynous ant population.

\section{Methods}

Sampling

Workers and reproductive queens of $F$. paralugubris were collected from 21 nests near the Chalet à Roch, in the Swiss Jura mountains. $F$. paralugubris has been recently separated from the sibling species $F$. lugubris (Seifert 1996), and the study population has previously been referred to as F. lugubris (e.g. Cherix 1980) or F. lugubris type B (Pamilo et al. 1992; Chapuisat 1996). Nests were located along a $1-\mathrm{km}$ transect within the supercolony. Sampling took place between mid-April and early May, when queens are close to the nest surface (Gösswald 1989). Ten workers per nest were stored in $95 \%$ ethanol for genetic analysis, 130 queens were frozen until dissection and genetic analyses of queens and sperm, and 50 queens were brought live to the laboratory to set up single-queen colonies and determine the genotype of their mates through mother-offspring analyses.

\section{Single-queen laboratory colonies}

Single queens were kept with approximately 200 workers in artificial colonies made from two ceramic flower pots. The ants were fed crickets, mealworms, maple syrup and water. After 1 month, mother queens, larvae and pupae were collected and frozen for 
subsequent genetic analyses (see below). Diploid offspring were obtained from 22 queens only, because 11 queens produced only haploid offspring, 4 died during the experiment, and 13 produced no offspring. As males are haploid and females diploid, the genotypes of the queens' mates can be inferred from mother-offspring genotypic data: at each locus, diploid offspring exhibit the paternal allele, together with one of the two maternal alleles. There was no case of a heterozygous queen producing only heterozygous offspring of the same genotype. Overall, the genotypes of 25 reproductive males were determined by this method (one queen had mated with two males, and one with three; Chapuisat 1998).

Analysis of the sperm stored in queens' spermatheca

Male genotypes can also be determined directly, by analysing with microsatellite markers the sperm stored in the queens' spermatheca (Peters et al. 1995; Chapuisat 1998). Sperm were extracted from a queen's spermatheca following the method described by Chapuisat (1998) and genotyped at four microsatellite markers (see below). When a queen had mated with multiple males, the exact multilocus genotype of each male could not be determined. To conduct relatedness measures, each detected allele was attributed at random to one of the males. This procedure does not affect relatedness measures, which are based on the combination of relative genetic similarities between all individuals, obtained from each independent locus (Queller and Goodnight 1989). Overall, genotypic data from 109 reproductive males were obtained by direct sperm typing.

\section{Microsatellite genotyping}

For each of the 21 nests, between 4 and 14 resident queens, the sperm from their spermathecas (if any), brood of single queens reared in artificial colonies (if any), and ten random workers were analysed with four microsatellite loci. These markers had between 3 and 13 alleles in the study sample. Methods and primers for microsatellite analysis have been described previously (Chapuisat 1996). Overall, genotypes were obtained from 176 queens, 134 of their mates and 210 workers from 21 nests.

\section{Statistical methods}

The relatedness is the probability that a random gene from an individual (the potential recipient of an altruistic act) has a copy identical by descent in an other individual (the potential actor). It was estimated using the method of Queller and Goodnight (1989), weighting groups equally. Standard errors were obtained by jackknifing over groups and $95 \%$ confidence intervals were constructed using the $t$-distribution with degrees of freedom equal to the number of groups minus 1 (Sokal and Rohlf 1995, p. 146). Relatedness was measured both within and between subgroups of nestmates (workers, reproductive queens and reproductive males). In the first case, mean relatedness among all members of a given subgroup was calculated. In the second case, the mean relatedness of one subgroup of individuals to the other was measured. Here, potential actors and recipients have to be specified, as the relatedness between them can be asymmetrical. In this paper, the "relatedness of $\mathrm{y}$ to $\mathrm{x}$ " means the relatedness of the recipient $\mathrm{y}$ to the actor x (Crozier and Pamilo 1980, 1996).

The fixation index $F$ is the correlation of alleles within individuals over all nests. $F$ is sometimes referred to as an inbreeding coefficient, and it reflects the deviation from random mating in the study population. Because genetic relatedness among nestmates is inflated by a positive fixation index (Pamilo 1984, 1985; Chapuisat et al. 1997), we used Pamilo's inbreeding correction to obtain an "inbreeding-adjusted" estimate of relatedness $r *$ which better reflects the number of reproducing individuals present in each nest (Pamilo 1984, 1985).

\section{Results}

Relatedness structure of $F$. paralugubris : empirical data

The mean relatedness obtained among all nestmates (workers, reproductive queens and reproductive males) was $0.14 \pm 0.01$ (mean $\pm \mathrm{SE}$; Table 1). This value is significantly greater than zero and is relatively high given the high number of queens present in each nest. However, this relatedness value is largely due to population microgeographic differentiation. The fixation index for all females was $0.07 \pm 0.02$ (Table 1), a value significantly greater than zero. This positive value indicates that mating is not random at the population level, confirming the result obtained in another sample of nests from the same population (Chapuisat et al. 1997). Removing the effect of non-random mating yields an inbreeding-adjusted nestmate relatedness $\left(r^{*}\right)$ of 0.03 for all nestmate females, a value that is compatible with a high effective queen number per nest (Table 1). When considered separately, queens and workers have similar relatedness and fixation coefficients (Table 1).

Detailed analysis of within-nest genetic relationships reveals that all castes of nestmates are related, the relatedness values being significantly greater than zero both within and between castes (Table 2). Because of haplodiploidy, the regression relatedness is asymmetrical between sexes, the relatedness of females to males being half that of males to females. When this asymmetry is taken into account, the relatedness values within and

Table 1 Relatedness $(r)$, fixation index $(F)$ and inbreedingadjusted relatedness $\left(r^{*}\right)$ among nestmates. Significance of the deviations from zero: $* P<0.05, * * P<0.01, * * * P<0.001$ (onetailed $t$-test, $d f=20$ )

\begin{tabular}{llll}
\hline & $r \pm \mathrm{SE}$ & $F \pm \mathrm{SE}$ & $r^{*}$ \\
\hline Workers & $0.16 \pm 0.02^{* * *}$ & $0.07 \pm 0.02^{* *}$ & 0.04 \\
Reproductive queens & $0.15 \pm 0.03^{* * *}$ & $0.05 \pm 0.03^{*}$ & 0.05 \\
Workers and & $0.15 \pm 0.02^{* * *}$ & $0.07 \pm 0.02^{* *}$ & 0.03 \\
$\quad$ reproductive queens & & & \\
$\quad \begin{array}{l}\text { Workers, reproductive } \\
\quad \text { queens and }\end{array}$ & $0.14 \pm 0.01^{* * *}$ & - & - \\
reproductive males & & & \\
\hline
\end{tabular}

Table 2 Relatedness ( \pm SE) within and between castes of nestmates. $95 \%$ confidence intervals are given in parentheses

\begin{tabular}{llll}
\hline Actor & Beneficiary & & \\
\cline { 2 - 4 } & Workers & $\begin{array}{l}\text { Reproductive } \\
\text { queens }\end{array}$ & $\begin{array}{l}\text { Reproductive } \\
\text { males }\end{array}$ \\
\hline Workers & $0.16 \pm 0.02$ & $0.13 \pm 0.02$ & $0.19 \pm 0.03$ \\
& $(0.13,0.19)$ & $(0.09,0.17)$ & $(0.13,0.25)$ \\
Reproductive & $0.14 \pm 0.02$ & $0.15 \pm 0.03$ & $0.14 \pm 0.03$ \\
queens & $(0.10,0.18)$ & $(0.09,0.21)$ & $(0.08,0.20)$ \\
$\begin{array}{c}\text { Reproductive } \\
\text { males }\end{array}$ & $0.09 \pm 0.01$ & $0.06 \pm 0.02$ & $0.15 \pm 0.07$ \\
\hline
\end{tabular}


between castes are very similar. Moreover, none differs significantly from the others, as shown by their largely overlapping confidence intervals (Table 2).

This pattern of within nest relatedness suggests that most queens are recruited from within the nest or come from closely located, genetically similar nests (Chapuisat et al. 1997). This is because the relatedness among queens is very similar to the relatedness among workers (Tables 1,2 ), the expected pattern if queens and workers have been produced in the same or closely located nests.

Queens' mates are also related, and their relatedness to other nestmates suggests that most of them mated within their natal nests (Table 2). The relatedness among queens' mates should be half the relatedness among queens or workers if all of them come from within the nest, and if many queens contribute equally to the production of male and female offspring. Indeed, the observed relatedness value among males is even greater, but not significantly so, than half the relatedness among queens or workers, indicating that most males are produced locally. The high rate of within-nest recruitment and prevalence of intranidal mating is further confirmed by the relatedness of males to queens which is very similar to the relatedness among queens, as expected if most of the males were produced by nestmate queens (Table 2 ).

Several lines of evidence suggest that mating within a nest occurs at random with respect to relatedness. First, the males are related to the queen with which they mated (Table 3). Second, the relatedness between queens and their mates is not significantly different from the relatedness between queens and the mates of other nestmate queens (Table 3). This suggests that queens mate at random with nestmate males, and do not select males less related to them. Third, the fixation index estimated from workers is consistent with queens and males mating at random within their natal nest. When related individuals mate in haplodiploid species, the fixation index of their offspring should be equal to the relatedness of the mother to the father, or to half the relatedness of the father to the mother (e.g. Hartl and Clark 1989, p. 564). The present study revealed that the fixation index of workers (0.07) is very close to the mean relatedness of queens to males (0.06) and to half the mean relatedness of the males to the queens $(0.14)$ (Tables 1,2$)$. Finally, random mating at the nest level is further confirmed by the absence of heterozygous deficit within nests $\left(F_{\text {individual-nest }}=0.001 \pm 0.04\right.$ for queens, $-0.02 \pm 0.03$ for workers, and $-0.01 \pm 0.03$ for all females).

Table 3 Relatedness $( \pm \mathrm{SE})$ between queens and their mates and between queens and the mates of nestmate queens $(n=109$ queens, 20 nests). $95 \%$ confidence intervals are given in parentheses

\begin{tabular}{lll}
\hline Actor & Beneficiary & \\
\cline { 2 - 3 } & Own mates & Mates of nestmate queens \\
\hline Mated queens & $0.17 \pm 0.05$ & $0.14 \pm 0.03$ \\
& $(0.06,0.28)$ & $(0.07,0.21)$ \\
\hline
\end{tabular}

Impact of the breeding system on the relatedness structure: model

Several models investigating how the breeding system affects the genetic relatedness among nestmates have been proposed. Most of these models assumed that males disperse and mate at random (Pamilo and VarvioAho 1979; Hughes et al. 1993; Queller 1993; Ross 1993). Another model assumed that all females arose as nestmates, and that gene flow among nests is performed by males only (Pamilo 1985). Hence, previous models relied on assumptions that are not satisfied in the $F$. paralugubris population under study, where both males and females show restricted dispersal.

Below, we develop a new model describing the dynamics of coancestry and relatedness among nestmates when a proportion $\alpha$ of the queens originate from within the nest and mate with nestmate males, and the remaining queens $(1-\alpha)$ come from the panmictic population after having mated at random. For simplicity, this model assumes that nestmate queens contribute equally to the production of males and females and that queens mate singly. This last point is a reasonable assumption in our study population where the effective mating frequency of queens is 1.11 (Chapuisat 1998).

The coancestry of two females $\mathrm{E}$ and $\mathrm{F}\left(f_{\mathrm{EF}}\right)$ is given by the mean of the four coancestries between their respective parents $\mathrm{A}, \mathrm{B}, \mathrm{C}$ and $\mathrm{D}$ :

$f_{\mathrm{EF}}=\frac{1}{4} f_{\mathrm{AC}}+\frac{1}{4} f_{\mathrm{AD}}+\frac{1}{4} f_{\mathrm{BC}}+\frac{1}{4} f_{\mathrm{BD}} \quad$ (Falconer 1960).

Pairs of nestmate females of the same generation fall into four distinct coancestry classes. First, they can have the same mother and father, both coming from the panmictic population and joining the nest after having mated at random. In this case, female offspring are outbred full sisters, and their coancestry is given by the following expression:

$f_{\text {sisters from migrant mother }}=\frac{3}{8}+\frac{1}{8} F_{(t-1)}=\frac{3}{8}+\frac{1}{8} \alpha f_{(t-2)}$,

where $F_{(t-1)}$ is the inbreeding coefficient of the mother, which is equal to the mean coancestry of nestmates two generations before $f_{(t-2)}$ multiplied by the proportion of intranidal mating $\alpha$. In a nest containing $n$ queens, the probability that females of the same generation belong to the class of coancestry described in Eq. 2 is $\frac{1}{n}(1-\alpha)$.

Second, nestmate females of the same generation can be full sisters whose mother came from within the nest and mated with a nestmate male, and their coancestry is given by the following expression:

$$
\begin{aligned}
f_{\text {sisters from local mother }} & =\frac{3}{8}+\frac{1}{8} F_{(t-1)}+\frac{1}{2} f_{\mathrm{p}} \\
& =\frac{3}{8}+\frac{1}{8} \alpha f_{(t-2)}+\frac{1}{2} f_{(t-1)},
\end{aligned}
$$

where $f_{\mathrm{p}}$ represents the coancestry among the parents, which is equal to the mean coancestry of the previous 
generation of nestmates $f_{(t-1)}$. The probability that female nestmates of the same generation fall into this class of coancestry is $\frac{1}{n} \alpha$.

Third, female nestmates can have different mothers that both came from within the nest, and their coancestry is given by Eq. 1. Note that because all parents came from within the nest, and mate at random at this level, $f_{\mathrm{AC}}=f_{\mathrm{AD}}=f_{\mathrm{BC}}=f_{\mathrm{BD}}=f_{(t-1)}$, and Eq. 1 reduces to the following expression:

$f_{\text {non sisters from local mothers }}=f_{(t-1)}$.

The probability that two females belong to the class of coancestry described in Eq. 4 is $\frac{(n-1)}{n} \alpha^{2}$.

Finally, if nestmates have different mothers with one or both mothers coming from the panmictic population, their coancestry is equal to zero.

Hence, the average coancestry of female nestmates of a given generation $f_{(t)}$ is given by

$$
\begin{aligned}
f_{(t)}= & \frac{1}{n}(1-\alpha)\left(\frac{3}{8}+\frac{1}{8} \alpha f_{(t-2)}\right) \\
& +\frac{1}{n} \alpha\left(\frac{3}{8}+\frac{1}{8} \alpha f_{(t-2)}+\frac{1}{2} f_{(t-1)}\right)+\frac{(n-1)}{n} \alpha^{2} f_{(t-1)}
\end{aligned}
$$

which can be rearranged as

$f_{(t)}=\frac{3}{8 n}+\left(\alpha^{2} \frac{n-1}{n}+\frac{\alpha}{2 n}\right) f_{(t-1)}+\frac{\alpha}{8 n} f_{(t-2)}$.

This recursion equation describes the change, from one generation to the next, in the coancestry among nestmates. If $n$ and $\alpha$ remain the same over generations, a stable level of nestmate coancestry $f_{e}$ is reached when $f_{(t)}=f_{(t-1)}=f_{(t-2)}$. Hence, Eq. 6 can be solved to yield $f_{e}:$

$f_{e}=\frac{3}{8 n-5 \alpha-8(n-1) \alpha^{2}}$.

Because relatedness and coancestries are linked by the following relationship:

$r_{y x}=\frac{f_{y x}}{f_{x x}}=\frac{2 f_{y x}}{\left(1+F_{x}\right)}$

(Hamilton 1972; Crozier and Pamilo 1996),

the relatedness at equilibrium is given by the following equation:

$r_{e}=\frac{2 f_{e}}{\left(1+\alpha f_{e}\right)}=\frac{3}{4 n-\alpha-4(n-1) \alpha^{2}}$.

Equation 9 gives the stable level of relatedness among female nestmates once a nest with $n$ queens and a rate of intranidal mating $\alpha$ has reached equilibrium (Fig. 1).

Application to the $F$. paralugxubris population

The model can be used to estimate the proportion of individuals mating and reproducing within or close to

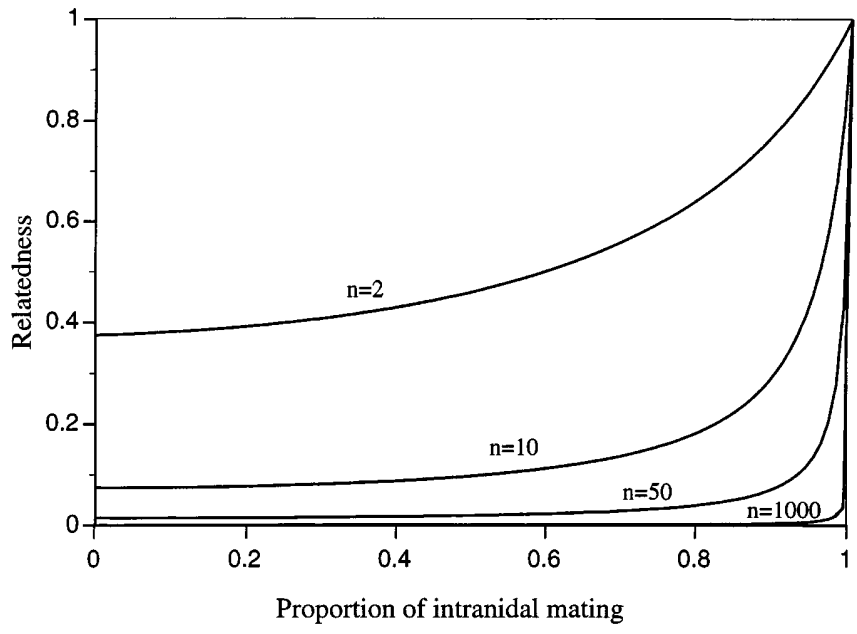

Fig. 1 Relatedness among worker nestmates at equilibrium as a function of the proportion of intranidal mating $(\alpha)$ and queen number (n)

their natal nest in our study population. If the effective number of nestmate queens is 1000 , then the observed relatedness among workers of 0.16 would be attained at equilibrium for a rate of intranidal mating of 0.998 . This means that only 2 out of 1000 queens would come from the surrounding population after having mated with unrelated males, all the other reproductive individuals being of local origin. The rate of local mating reduces to only 0.996 and 0.980 if the effective number of queens is 500 and 100 , respectively. Moreover, the estimated rate of local mating remains as high as 0.997 and 0.974 for 1000 and 100 queens, respectively, when the lower limit of the $95 \%$ confidence interval of worker relatedness $(r=0.127)$ is used. Hence, the estimated rate of local mating is relatively insensitive to variations in both effective queen number and relatedness measures, and it remains very high when calculated in a conservative manner. The model and the empirical data clearly show that the vast majority of the queens and males reproducing in the study population had mated in their natal nest, or close to it, with queens remaining in their natal or in a neighbouring nest after mating.

\section{Discussion}

The main finding of this study is that both queens and males show very limited dispersal in this highly polygynous and largely unicolonial wood ant population. New reproductive individuals are recruited almost exclusively from within the nest, or from closely located nests which have been shown to be genetically similar (Chapuisat et al. 1997). Our model, combined with the genetic data, indicates that as many as $99.8 \%$ of the reproducing queens had mated with nestmate males, and remained in or close to their natal nest after mating. Hence, nests of $F$. paralugubris are relatively closed 
entities, where numerous queens and males have been recruited over many generations.

These data contrast sharply with the common view that gene flow among distant nests is unrestricted in highly polygynous, unicolonial populations. Indeed, the amount of gene flow among distant nests is extremely low in F. paralugubris, despite the fact that all nests belong to the same supercolony (Cherix 1980), and are separated by at most $1 \mathrm{~km}$. This restricted gene flow is particularly surprising when considering that no sign of aggression was detected between workers from distant nests, and that nearby nests are connected by trails with ongoing exchanges of workers (Gris and Cherix 1977; Cherix 1980; M. Chapuisat, unpublished data). The rate of acceptance of unrelated queens coming from distant nests is probably not higher in F. paralugubris than in weakly polygynous species with well-developed nestmate recognition. Data on the distribution of mitochondrial haplotypes exist for three such species, and in all of them some nests contained several haplotypes. The minimum proportion of nests with multiple matrilines ranged between 6 and $35 \%$, indicating that unrelated queens are occasionally adopted in nests of weakly polygynous species (Stille and Stille 1992; Carew et al. 1997; Tay et al. 1997). In contrast, acceptance of unrelated queens seems common in the highly polygynous ant Solenopsis invicta, resulting in relatedness among nestmate queens very close to zero both for nuclear and mitochondrial markers (Goodisman and Ross 1998).

The breeding system uncovered in $F$. paralugubris has important implications for our understanding of the maintenance of altruism in highly polygynous species. A high rate of intranidal mating and limited dispersal result in significant genetic differentiation among nests in $F$. paralugubris, with nestmates being more related than random individuals of the local population. Such population viscosity does not promote altruism if relatives compete for local resources (Pollock 1983; Taylor 1992a, b). However, part of the competition may occur over a larger scale in $F$. paralugubris, particularly when new queens and males fly off from their natal nest and disperse further than the supercolony limits (Cherix et al. 1991). Hence, workers may increase their inclusive fitness if altruism occurs before dispersal of new reproductive individuals, as dispersing queens and males will compete with less related non-nestmate individuals. Workers may obtain indirect fitness benefits by helping to rear nestmate queens that will disperse to neighbouring nests, or that will disperse further and found new colonies by usurping nests of other Formica species. Indeed, signs of both processes have been found in the genetic structure of this population (Chapuisat et al. 1997). Additionally, workers might also increase their inclusive fitness by helping preferentially the queens that are more related to them (Crozier and Pamilo 1996). However, such within-nest nepotism has not been detected in the three polygynous ant species examined for it (Carlin et al. 1993; Snyder 1993; DeHeer and Ross 1997).
Limited dispersal and intranidal mating should also entail costs, because related individuals are more likely to share identical alleles at the sex-determining locus, thus producing diploid males which usually have reduced fertility (Cook and Crozier 1995). However, a high rate of intranidal mating does not necessarily translate into elevated inbreeding and massive production of diploid males in highly polygynous colonies, because the presence of numerous queens ensures a high level of within nest genetic diversity. For example, a rate of intranidal mating as high as 0.998 results in an overall level of inbreeding of only 0.07 if the effective queen number is 1000 . Hence, if there is a single sex locus, about $7 \%$ of the diploid eggs would develop into males because of inbreeding. The frequency of diploid males has not been investigated in $F$. paralugubris, but between 1 and $10 \%$ of the males were diploid in five other highly polygynous Formica species (Pamilo et al. 1994). These values are consistent with moderate levels of inbreeding due to limited dispersal.

The mating system described in F. paralugubris may be common to many highly polygynous ant species. Intranidal mating and recruitment of new queens from within the nest is very frequent in highly polygynous species (Passera 1994). For example, mating occurs mostly within the nest in the Argentine ant Linepithema humile and there is little dispersal by males on the wing (Keller and Passera 1992; Passera and Keller 1994). The relatedness structure of a polygynous population of $F$. truncorum also suggests that daughter queens are recruited in their mother nest, after having mated with nestmate males (Sundström 1993). Reproductive males of Myrmica sulcinodis are also related, indicating that mating occurs mostly locally in this species as well (Pedersen and Boomsma 1998).

Data on genetic differentiation within populations further suggest that both local mating and colony reproduction by budding are frequent in highly polygynous species. Microgeographic genetic differentiation has been detected in $F$. paralugubris (Chapuisat et al. 1997) and in many other polygynous ants (Halliday 1983; Pamilo 1983; Crozier et al. 1984; Pamilo and Rosengren 1984; Boomsma et al. 1990; Stille and Stille 1993; Herbers and Grieco 1994; Seppä and Pamilo 1995; Banschbach and Herbers 1996; Ross et al. 1997; Tay et al. 1997). In contrast, microgeographic genetic differentiation seems to be rare in monogynous ants, which is not surprising, because queens of monogynous species usually mate with non-nestmate males and frequently disperse over large distances before initiating a new colony (Bourke and Heinze 1994; Crozier and Pamilo 1996).

To date, an absence of microgeographic genetic differentiation at nuclear loci coupled with a relatedness among nestmates indistinguishable from zero has been found in only one highly polygynous species, the fire ant S. invicta in the USA (Ross et al. 1996; Ross and Shoemaker 1997; Goodisman and Ross 1998). A similar situation may also occur in the Argentine ant 
Linepithema humile (Kaufmann et al. 1992), but microgeographic genetic differentiation has not been specifically investigated in this species. Importantly, these studies of $S$. invicta and L. humile concerned recently established populations that have been introduced by humans. Hence, unicolonial organization seems to arise under two very distinct sets of ecological conditions, resulting in contrasted within-population genetic structures. On the one hand, the lack of microgeographic genetic differentiation in species such as $S$. invicta and possibly $L$. humile may stem from their extremely opportunistic habits, that make them efficient colonisers of new or empty habitats (Passera 1994). In these species, indiscriminate acceptance of unrelated queens and unrestricted gene flow among distant nests may arise from the loss of discrimination cues during a severe population bottleneck at the time of colonisation (Ross et al. 1987; Crozier and Pamilo 1996), or may be driven by the lack of competitors and natural enemies in the new habitat. On the other hand, the strong genetic microdifferentiation detected in $F$. paralugubris is probably associated with the exploitation of a stable habitat in which resources can be progressively enhanced over time. In particular, wood ants construct elaborate nests, and increase their food supply by tending aphids (Gösswald 1989). Such conditions may lead to the monopolisation of patches of habitat by extended family groups composed of multiple generations. Locally unicolonial populations would thus arise through a combination of local recruitment of new queens and males, exclusion of reproductive individuals coming from distant nests, and nest-budding.

In conclusion, this study shows that the evolution of colonies with very high queen number in $F$. paralugubris has been accompanied with a complete shift in the breeding system. Instead of dispersing, and mating with foreign unrelated males, queens typically stay in their natal nest in which they mate with males of the same origin. The formation of new colonies occurs mostly through budding, with some rare queens able to parasitise the nest of other species (Chapuisat et al. 1997). This breeding system and mode of colony reproduction result in significant genetic differentiation among nests, with the effect that nestmates are related compared to other individuals of the same population. This type of breeding system and ensuing genetic structuring is probably common to many highly polygynous ant species, and may play an important role in the evolution and maintenance of ant colonies with high numbers of queens.

Acknowledgements We thank W.D. Brown, R.H. Crozier, M.A.D. Goodisman, P. Pamilo, J.S. Pedersen, F.W.L. Ratnieks, K.G. Ross, D.C. Queller, P. Seppä, G.J. Thompson and an anonymous reviewer for comments on the manuscript. This study was supported by the Swiss National Science Foundation (grant 81LA51147 to M.C., grants 31-43330.95, 31-49679.96 to L.K.) and by the Société Académique Vaudoise. The experiments described in this paper were conducted in accordance with local and federal laws in Switzerland.

\section{References}

Banschbach VS, Herbers JM (1996) Complex colony structure in social insects. I. Ecological determinants and genetic consequences. Evolution 50:285-297

Boomsma JJ, Brouwer AH, Van Loon AJ (1990) A new polygynous Lasius species (Hymenoptera: Formicidae) from central Europe. II. Allozymatic confirmation of species status and social structure. Insectes Soc 37:363-375

Bourke AFG, Franks NR (1995) Social evolution in ants. Princeton University Press, Princeton, NJ

Bourke AFG, Heinze J (1994) The ecology of communal breeding: the case of multiple-queen leptothoracine ants. Phil Trans R Soc Lond B 345:359-372

Carew ME, Tay WT, Crozier RH (1997) Polygyny via unrelated queens indicated by mitochondrial DNA variation in the Australian meat ant Iridomyrmex purpureus. Insectes Soc 44:7-14

Carlin NF, Reeve HK, Cover SP (1993) Kin discrimination and division of labour among matrilines in the polygynous carpenter ant, Camponotus planatus. In: Keller L (ed) Queen number and sociality in insects. Oxford University Press, Oxford, pp 362-401

Chapuisat M (1996) Characterization of microsatellite loci in Formica lugubris $B$ and their variability in other ant species. Mol Ecol 5:599-601

Chapuisat M (1998) Mating frequency of ant queens with alternative dispersal strategies, as revealed by microsatellite analysis of sperm. Mol Ecol 7:1097-1105

Chapuisat M, Goudet J, Keller L (1997) Microsatellites reveal high population viscosity and limited dispersal in the ant Formica paralugubris. Evolution 51:475-482

Cherix D (1980) Note préliminaire sur la structure, la phénologie et le régime alimentaire d'une super-colonie de Formica lugubris Zett. Insectes Soc 27:226-236

Cherix D (1983) Pseudogynes (=sécrétergates) et répartition des individus à l'intérieur d'une fourmilière de Formica lugubris Zett. (Hymenoptera: Formicidae). Insectes Soc 30:184-192

Cherix D, Chautems D, Fletcher DJC, Fortelius W, Gris G, Keller L, Passera L, Rosengren R, Vargo EL, Walter F (1991) Alternative reproductive strategies in Formica lugubris Zett. (Hymenoptera: Formicidae). Ethol Ecol Evol Spec Issue 1:61-66

Cherix D, Fletcher DJC, Chautems D, Fortelius W, Gris G, Keller L, Rosengren R, Vargo E, Walter F (1993) Attraction of the sexes in Formica lugubris Zett. (Hymenoptera: Formicidae). Insectes Soc 40:319-324

Cook J, Crozier RH (1995) Sex determination and population biology in the Hymenoptera. Trends Ecol Evol 10:281-286

Crozier RH, Pamilo P (1980) Asymmetry in relatedness: who is related to whom? Nature 283:604

Crozier RH, Pamilo P (1996) Evolution of social insect colonies: sex allocation and kin selection. Oxford University Press, Oxford

Crozier RH, Pamilo P, Crozier YC (1984) Relatedness and microgeographic genetic variation in Rhytidoponera mayri, an Australian arid-zone ant. Behav Ecol Sociobiol 15:143-150

DeHeer CJ, Ross KG (1997) Lack of detectable nepotism in multiple-queen colonies of the fire ant Solenopsis invicta (Hymenoptera: Formicidae). Behav Ecol Sociobiol 40:27-33

Falconer DS (1960) Introduction to quantitative genetics. Ronald, New York

Fortelius W, Rosengren R, Cherix D, Chautems D (1993) Queen recruitment in a highly polygynous supercolony of Formica lugubris (Hymenoptera: Formicidae). Oikos 67:193-200

Goodisman MAD, Ross KG (1998) A test of queen recruitment models using nuclear and mitochondrial markers in the fire ant Solenopsis invicta. Evolution 52:1416-1422

Gösswald K (1989) Die Waldameise. Band 1. Biologische Grundlagen, Ökologie und Verhalten. Aula, Wiesbaden

Gris G, Cherix D (1977) Les grandes colonies de fourmis des bois du Jura (groupe Formica rufa). Mitt Schweiz Entomol Ges $50: 249-250$ 
Halliday RB (1983) Social organization of meat ants Iridomyrmex purpureus analysed by gel electrophoresis of enzymes. Insectes Soc 30:45-56

Hamilton WD (1963) The evolution of altruistic behavior. Am Nat 97:354-356

Hamilton WD (1964a) The genetical evolution of social behaviour. I. J Theor Biol 7:1-16

Hamilton WD (1964b) The genetical evolution of social behaviour. II. J Theor Biol 7:17-52

Hamilton WD (1972) Altruism and related phenomena, mainly in social insects. Annu Rev Ecol Syst 3:193-232

Hartl DL, Clark AG (1989) Principles of population genetics. Sinauer, Sunderland, Mass

Herbers JM (1986) Nest site limitation and facultative polygyny in the ant Leptothorax longispinosus. Behav Ecol Sociobiol 19:115-122

Herbers JM, Grieco S (1994) Population structure of Leptothorax ambiguus, a facultatively polygynous and polydomous ant species. J Evol Biol 7:581-598

Hölldobler B, Wilson EO (1977) The number of queens: an important trait in ant evolution. Naturwissenschaften 64:8-15

Hölldobler B, Wilson EO (1990) The ants. Springer, Berlin Heidelberg New York

Hughes CR, Queller DC, Strassmann JE, Solis CR, Negrón-Sotomayor JA, Gastreich KR (1993) The maintenance of high genetic relatedness in multi-queen colonies of social wasps. In: Keller L (ed) Queen number and sociality in insects. Oxford University Press, Oxford, pp 153-170

Kaufmann B, Boomsma JJ, Passera L, Petersen KN (1992) Relatedness and inbreeding in a French population of the unicolonial ant Iridomyrmex humilis (Mayr). Insectes Soc 39:195-200

Keller L (1995) Social life: the paradox of multiple-queen colonies. Trends Ecol Evol 10:355-360

Keller L, Passera L (1989) Size and fat content of gynes in relation to the mode of colony founding in ants (Hymenoptera: Formicidae). Oecologia 80:236-240

Keller L, Passera L (1992) Mating system, optimal number of matings, and sperm transfer in the Argentine ant Iridomyrmex humilis. Behav Ecol Sociobiol 31:359-366

Kutter H (1977) Hymenoptera, Formicidae. Schweizerische Entomologische Gesellschaft, Zürich

Nonacs P (1988) Queen number in colonies of social Hymenoptera as a kin-selected adaptation. Evolution 42:566-580

Pamilo P (1983) Genetic differentiation within subdivided populations of Formica ants. Evolution 37:1010-1022

Pamilo P (1984) Genotypic correlation and regression in social groups: multiple alleles, multiple loci and subdivided populations. Genetics 107:307-320

Pamilo P (1985) Effect of inbreeding on genetic relatedness. Hereditas 103:195-200

Pamilo P, Rosengren R (1984) Evolution of nesting strategies of ants: genetic evidence from different population types of Formica ants. Biol J Linn Soc 21:331-348

Pamilo P, Varvio-Aho SL (1979) Genetic structure of nests in the ant Formica sanguinea. Behav Ecol Sociobiol 6:91-98

Pamilo P, Chautems D, Cherix D (1992) Genetic differentiation of disjunct populations of the ants Formica aquilonia and Formica lugubris in Europe. Insectes Soc 39:15-29

Pamilo P, Sundström L, Fortelius W, Rosengren R (1994) Diploid males and colony-level selection in Formica ants. Ethol Ecol Evol 6:221-235

Passera L (1994) Characteristics of tramp species. In: Williams DF (ed) Exotic ants: biology, impact, and control of intoduced species. Westview Press, Boulder, Colo, pp 23-43
Passera L, Keller L (1994) Mate availability and male dispersal in the Argentine ant Linepithema humile (Mayr) (=Iridomyrmex humilis). Anim Behav 48:361-369

Pedersen JS, Boomsma JJ (1998) Direct genetic evidence for local mate competition in ants. Naturwissenschaften 85:593-595

Peters JM, Queller DC, Strassmann JE, Solís CR (1995) Maternity assignment and queen replacement in a social wasp. Proc R Soc Lond B 260:7-12

Pollock GB (1983) Population viscosity and kin selection. Am Nat 122:817-829

Queller DC (1993) Genetic relatedness and its components in polygynous colonies of social insects. In: Keller L (ed) Queen number and sociality in insects. Oxford University Press, Oxford, pp 132-152

Queller DC, Goodnight KF (1989) Estimating relatedness using genetic markers. Evolution 242:258-275

Ross KG (1993) The breeding system of the fire ant Solenopsis invicta: effects on colony genetic structure. Am Nat 141:554-576

Ross KG, Shoemaker DD (1997) Nuclear and mitochondrial genetic structure in two social forms of the fire ant Solenopsis invicta: insights into transitions to an alternate social organization. Heredity 78:590-602

Ross KG, Vargo EL, Fletcher DJC (1987) Comparative biochemical genetics of three fire ant species in North America, with special reference to the two social forms of Solenopsis invicta (Hymenoptera: Formicidae). Evolution 41:979-990

Ross KG, Vargo EL, Keller L (1996) Social evolution in a new environment: the case of introduced fire ants. Proc Natl Acad Sci USA 93:3021-3025

Ross KG, Krieger MJB, Shoemaker DD, Vargo EL, Keller L (1997) Hierarchical analysis of genetic structure in native fire ant populations: results from three classes of molecular markers. Genetics 147:643-655

Seifert B (1996) Formica paralugubris nov. spec. - a sympatric sibling species of Formica lugubris from the westen Alps (Insecta: Hymenoptera: Formicoidea: Formicidae). Reichenbachia 31:193-201

Seppä P, Pamilo P (1995) Gene flow and population viscosity in Myrmica ants. Heredity 74:200-209

Snyder LE (1993) Non-random behavioural interactions among genetic subgroups in a polygynous ant. Anim Behav 46:431-439

Sokal RR, Rohlf FJ (1995) Biometry. Freeman, New York

Stille M, Stille B (1992) Intra- and inter-nest varation in mitochondrial DNA in the polygynous ant Leptothorax acervorum (Hymenoptera: Formicidae). Insectes Soc 39:335-340

Stille M, Stille B (1993) Intrapopulation nestclusters of maternal mtDNA lineages in the polygynous ant Leptothorax acervorum (Hymenoptera: Formicidae). Insect Mol Biol 1:117-121

Sundström L (1993) Genetical population structure and sociogenetic organisation in Formica truncorum. Behav Ecol Sociobiol $33: 345-354$

Tay WT, Cook JM, Rowe DJ, Crozier RH (1997) Migration between nests in the Australian arid-zone ant Rhytidoponera sp. 12 revealed by DGGE analyses of mitochondrial DNA. Mol Ecol 6:403-411

Taylor PD (1992a) Altruism in viscous populations - an inclusive fitness model. Evol Ecol 6:352-356

Taylor PD (1992b) Inclusive fitness in a homogeneous environment. Proc R Soc Lond B 249:299-302

Wilson EO (1971) The insect societies. Harvard University Press, Cambridge, Mass

Communicated by P. Pamilo 